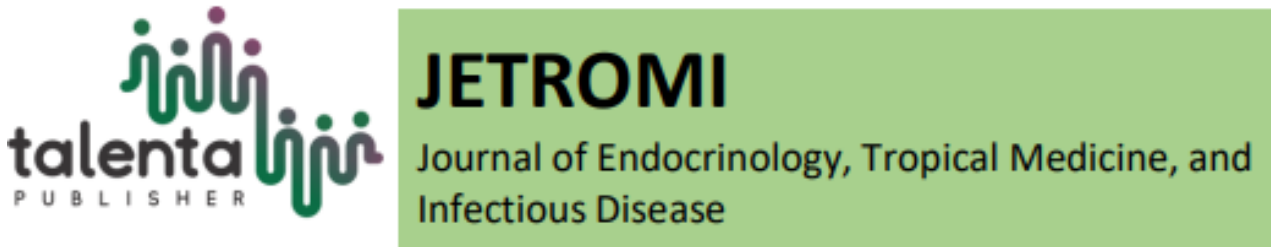

\title{
Self-Perception of Co-Assistant Students Regarding The Covid-19 Pandemic
}

\author{
Chairiza Muttaqien", Putri Chairani Eyanoer ${ }^{2}$, Ririe Fachrina Malisie ${ }^{3}$, and Hemma \\ Yulfi $^{4}$ \\ ${ }^{1}$ Faculty of Medicine, Universitas Sumatera Utara, Medan, North Sumatera, Indonesia \\ ${ }^{2}$ Departement of Community Medicine, Universitas Sumatera Utara, Medan, North Sumatera, Indonesia \\ ${ }^{3}$ Departement of Pediatric, Universitas Sumatera Utara, Medan, North Sumatera, Indonesia \\ ${ }^{4}$ Departement of Parasitology, Universitas Sumatera Utara, Medan, North Sumatera, Indonesia
}

\begin{abstract}
Background: At the beginning of 2020, the world was shocked by a new type of coronavirus (SARS-CoV-2) whose disease was called Coronavirus disease 2019 (COVID-19). The research aims to determine the self-perception of Co-Assistant students regarding the COVID-19 pandemic.

Method: The study was designed cross-sectional, which was conducted via sharing online links. Respondents must Co-Assistant students from a medical faculty in Indonesia and participated in the questionnaire filling between June 2020 and October 2020. This research is a descriptive study with a cross-sectional approach and conducted using primary data (online questionnaire)

Results: One hundred forty-nine students (149) of Co-Assistant students from several medical faculties all over Indonesia met the inclusive criteria. The samples were dominated by female respondents at 103 students $(69.1 \%)$, while the male respondent accounted for only 46 students (30.9\%). The first year of the Co-Assistant program with 94 respondents (63.1\%) followed by the second year of the Co-Assistant program with 55 respondents (36.9\%). The highest mean score in the fear zone came from the "first year of Co-Assistant program" group and the highest mean score in the learning and growth zone came from the "second year of Co-Assistant program" group.
\end{abstract}

Conclusion: The highest mean score in the fear zone came from the "first year of CoAssistant program" group and the highest mean score in the learning and growth zone came from the "second year of Co-Assistant program" group.

Keyword: Covid-19, Fear Zone, Growth Zone, Learning Zone.

*Corresponding author at: Faculty of Medicine, Universitas Sumatera Utara, Medan, North Sumatera, Indonesia E-mail address: rizamuttaqin880@gmail.com 
ABSTRAK

Latar Belakang: Pada awal 2020, dunia dikejutkan dengan virus corona jenis baru (SARSCoV-2) yang penyakitnya disebut Coronavirus disease 2019 (COVID-19). Penelitian ini bertujuan untuk menentukan persepsi diri siswa Co-Assistant mengenai pandemi COVID19.

Metode: Studi ini dirancang secara potong lintang, yang dilakukan melalui online. Responden harus Co-Assistant dari fakultas kedokteran di Indonesia dan berpartisipasi dalam pengisian kuesioner antara Juni 2020 dan Oktober 2020. Penelitian ini bersifat deskriptif dengan data primer (kuesioner online)

Hasil: Dari 149 siswa CoAsisten dari beberapa fakultas kedokteran di seluruh Indonesia yang memenuhi kriteria inklusif, didominasi oleh responden perempuan pada 103 siswa (69,1\%), sedangkan responden laki-laki hanya 46 siswa (30,9\%). Tahun pertama program Co-Assistant dengan 94 responden $(63,1 \%)$ diikuti oleh tahun kedua program Co-Assistant dengan 55 responden (36,9\%). Skor rata-rata tertinggi di zona ketakutan berasal dari kelompok tahun pertama Co-Assistant dan skor rata-rata tertinggi dalam pembelajaran dan growth berasal dari kelompok tahun kedua program Co-Assistant.

Kesimpulan: Skor rata-rata tertinggi di zona ketakutan berasal dari kelompok tahun pertama program Co-Assistant, dan skor rata-rata tertinggi di zona pembelajaran dan growth dari kelompok tahun kedua program Co-Assistant.

Kata kunci: Covid-19, Zona Ketakutan, Zona Pertumbuhan, Zona Belajar,

Received 8 March 2021 | Revised 30 May 2021 | Accepted 31 May 2021

\section{Introduction}

At the beginning of 2020, the world was shocked by the outbreak of a new virus, namely a new type of coronavirus (SARS-CoV-2), and the disease is called Coronavirus disease 2019 (COVID19). It is known that the origin of this virus came from Wuhan, Central China, and has spread to many countries around the world. The first case of coronavirus was reported on December 31, 2019 , in Wuhan. But at that time, it was not clear what caused the disease with pneumonia symptoms [1].

On February 11, 2020, the World Health Organization (WHO) named the new virus as Severe Acute Respiratory Syndrome Coronavirus-2 (SARS-CoV-2) and the name of the disease as Coronavirus disease 2019 (COVID-19) [2]. It was confirmed that this transmission of pneumonia can be transmitted from human to human [3]. Until now, research is still being carried out to determine the characteristics and also to get a vaccine from SARS-CoV-2.

On April 11, 2020, 213 countries have confirmed positive cases of COVID-19 in their countries, with a total of 1,610,909 cases and 99,690 deaths. From these data, it was found that the case fatality rate around the world was $6.2 \%$. The United States is the country with the most COVID- 
19 cases in the world, with 461,275 cases, followed by Spain with 157,022 cases, and Italy with 147,577 cases [4].

In Indonesia, on April 11, 2020, there were 3,842 positive cases of COVID-19, with 327 deaths, and 286 patients had recovered. From these data, the case fatality rate in Indonesia was $8.5 \%$. This condition concerned us because the case fatality rate of COVID-19 cases in Indonesia is greater than the case fatality rate in the world [5].

Perception is a person's ability to distinguish, classify, and focus an observation. Therefore a person can have different perceptions even though the object is the same. This is possible because of differences in value systems and personality traits of the individual concerned [6].

Everyone can have a different view or perception of the COVID-19 pandemic. Some feel angry with the situation, some have started to accept the situation, and some have even started thinking about how to help others. A person's perception of COVID-19 certainly influences the actions that will be taken. The more people who have a good perception of COVID-19, the better action will be taken and this can have a positive impact on the response to COVID-19.

Co-Assistant students are medical students who are studying at the clinical stage, in a hospital. Their self-perception regarding the COVID-19 pandemic is interesting to be studied. Researchers are also interested because research about COVID-19 pandemic whose samples are Co-Assistant students is still rarely conducted.

This self-perception assessment is based on Anastasia Ediati's infographic, which adapts the psychological zones as a reference for detecting psychological conditions during a pandemic. There are fear zone, learning zone, and growing zone.

\section{Methods}

The study was designed cross-sectional, which was conducted via sharing online links. Respondents must Co-Assistant students from a medical faculty in Indonesia and participated in the questionnaire filling between June 2020 and October 2020. A total of 149 respondents originated from medical faculties all over Indonesia.

The questionnaire consists of a study explanation, informed consent, and questions. There are two sub-sections in the question section, such as identity (name, gender, age, medical faculty origin, etc) and self-perception. The self-perception section consists of 20 questions. Five questions from the fear zone, seven questions from the learning zone, and eight questions from the growth zone.

The higher fear zone score indicates that the respondent is better at coping with anxiety, worry, or fear and controlling activities or behavior in the fear zone, for example, panic buying or buying goods such as drugs and masks excessively. The higher learning zone score indicates that the 
respondent is getting better at accepting the fact that they are experiencing the COVID-19 pandemic, starting to comply with government advice or protocols, being able to control emotions, and starting to spend less, and planning better actions. The higher growth zone score indicates that respondents are better at maintaining their emotions to stay happy and empathize with one another.

Each question consisted of answers with five options, such as "strongly agree", "agree", "undecided", "disagree", and "strongly disagree" (Likert scale). The same option can get a different point regarding the zone. In the fear zone, option "strongly agree" means 1 point, option "agree" means 2 points, option "undecided" means 3 points, option "disagree" means 4 points, and option "strongly disagree" means 5 point. In the learning and growth zone, option "strongly agree" means 5 points, option "agree" means 4 points, option "undecided" means 3 points, option "disagree" means 2 points, and option "strongly disagree" means 1 point.

The maximum score for each question is five. Based on each zone, it is known that the maximum score for each zone is 25 for the fear zone, 35 for the learning zone, and 40 for the growth zone.

The questionnaire was designed and disseminated using a google form since this platform was easy to access by respondents. Furthermore, a survey model using google Forms is widespread in terms of both familiarity and reproducibility for online-based-survey. Google forms could also be distributed just in a brief period via rapid link sharing using copy-paste shortcuts to other social media platforms, including the Whatsapp group.

Statistical analysis

Data were processed with Statistical Package for Social Science (SPSS) software with descriptive analysis to calculate frequency distribution, mean, and deviation standard.

\section{Result}

One hundred forty-nine students (149) of Co-Assistant students from several medical faculties all over Indonesia met the inclusive criteria and the characteristics of the samples recorded were sex and year of the program

Table 1 . Characteristics of Respondents

\begin{tabular}{lcc}
\hline \multicolumn{1}{c}{ Characteristics } & $\mathrm{n}$ & $\%$ \\
\hline Gender & & \\
Male & 46 & 30.9 \\
Female & 103 & 69.1 \\
Year of Co-Assistant program & & \\
First-year & 94 & 63.1 \\
Second-year & 55 & 36.9 \\
\hline
\end{tabular}


Table 1 shows that the samples were dominated by female respondents at 103 students (69.1\%), while the male respondent accounted for only 46 students (30.9\%). Another dominant characteristic was the first year of the Co-Assistant program with 94 respondents $(63.1 \%)$ followed by the second year of the Co-Assistant program with 55 respondents (36.9\%). Mean Score of self-perception regarding the COVID-19 pandemic

Table 2 . Mean Score of self-perception regarding the COVID-19 pandemic

\begin{tabular}{ccc}
\hline Zone & $\begin{array}{c}\text { First Year of Co-Assistant } \\
\text { Program }\end{array}$ & $\begin{array}{c}\text { Second Year of Co-Assistant } \\
\text { Program }\end{array}$ \\
\hline Fear Zone & $19.47 \pm 2.679$ & $18.42 \pm 2.948$ \\
Learning Zone & $28.17 \pm 2.474$ & $28.95 \pm 2.571$ \\
Growth Zone & $33.73 \pm 2.852$ & $34.35 \pm 3.001$ \\
\hline
\end{tabular}

Table 2 shows that the highest mean score in the fear zone came from the "first year of CoAssistant program" group and the highest mean score in the learning and growth zone came from the "second year of Co-Assistant program" group.

\section{Discussion}

One of the factors that influence the formation of perceptions is the personal condition of the person perceiving, for example, education and past experiences [7]. Education and past experiences will provide a basis for thinking, understanding, views, or individual responses to something around them (7). Based on the level of education and clinical experience, of course, the "second year of Co-Assistant program" group is at the top level, followed by the "first year of Co-Assistant program" group.

However, a result that contradicts the above theory is seen in the mean score of the fear zone. The highest mean score in the fear zone came from "the first year of the Co-Assistant program" group. Results that compatible with the above theory are seen in the mean score of learning and growth zone. Researchers hope that in the future, more similar studies will be carried out by analyzing the factors that affect each zone.

The mean score for each zone did not reach the maximum, of course, due to the influence of various factors, one of which was because this pandemic was something new or something that had not happened in the world for a long time after the Spanish flu pandemic in 1918-1920. dr. Maria Van Kerkhove, an expert from the World Health Organization or WHO, stated that within 6 months since the SARS-CoV-2 virus was identified, humans still need to learn a lot about the virus and the diseases it causes [8].

\section{Conclusion}

Based on the author's knowledge, this is the first "self-perception of Co-Assistant students regarding the COVID-19 pandemic" study conducted in Indonesia. The highest mean score in the 
fear zone came from the "first year of Co-Assistant program" group that contradicts the perception theory and the highest mean score in the learning and growth zone came from the "second year of Co-Assistant program" group. Researchers hope that in the future, more similar studies will be carried out by analyzing the factors that affect each zone.

\section{REFERENCES}

[1] Kementerian Kesehatan Republik Indonesia. COVID-19 dashboard, 2020.

[2] Mukhtar, D. Y., Gambaran Persepsi Masyarakat Kota Medan Terhadap Pendidikan Inklusi Studi Terhadap Beberapa Kecamatan di Kota Medan, 2013.

[3] Ramadhan, B. F., Gambaran persepsi keselamatan berkendara sepeda motor pada siswa/i sekolah menengah atas di Kota Bogor tahun 2009. Skripsi. Jakarta: Universitas Indonesia, 2009.

[4] Ramadhan, Komite Penanganan Covid-19 dan Pemulihan Ekonomi Nasional. Lengkapi Informasi Covid-19 dari Sumber Resmi. [online]. Available on: https://covid19.go.id/p/berita/lengkapi-informasi-dan-pengetahuan-covid-19-darisumber-resmi. [Accessed: Desember 11, 2020].

[5] Relman E, Business insider Singapore. [online]. Available on:https://www.businessinsider.sg/deadly-china-Wuhan-virusspreading-human-tohuman-officials-confirm-2020-1/?r=US\&IR=T. [Accessed: January 28, 2020].

[6] WHO. Novel Coronavirus (2019-nCoV) Situation Report-1. January 21, 2020.

[7] WHO. WHO Director-General's remarks at the media briefing on 2019-Nov on 11 February 2020. [online]. Available on: https://www.who.int/dg/speeches/detail/whodirector-generals-remarks-at-the-media-briefing-on-2019-ncov-on-11-february-2020. [Accessed: February 13, 2020].

[8] World Health Organization. WHO COVID-19 dashboard, 2020. 